\title{
FERTILITY PROCESSES IN UKRAINE FROM THE STANDPOINT OF HUMAN GEOGRAPHY
}

\author{
Iryna HUDZELYAK \\ Ivan Franko National University of Lviv \\ ihudzelyak@gmail.com
}

\begin{abstract}
In Ukraine, during the twentieth century, the birth rate steadily declined, with the exception of two short-term postwar periods. Since the beginning of XXI century, there is a slow increase in fertility after the low level during the crisis in 2001 . Among the factors, along with social and gender characteristics and specific demographic structure, major influence belongs to population policy, while the level of socio-economic development makes controversial and unusual effects on fertility. Reproductive health in Ukraine is unsatisfactory, which is caused by current lifestyle, vital behaviour, spread of abortions, particularly among the youngest age groups. In general, abortion rates are declining; there are very substantial spatial differences. Features of the modern age structure of fertility were revealed, that are important for assessing the stage of demographic transition and defining new models of demographic behaviour. The Western Ukraine has the lowest level of early (except the Transcarpathian Region) and illegitimate births. Typology of Ukrainian regions, conducted based on level, structure and birth tendencies indicators, make possible to highlight ten groups of regions and describe major spatial differences. Most adverse trends in fertility can be observed in Sumy, Chernihiv, Luhansk, Donetsk, Kharkiv, Poltava and Cherkasy regions, while the positive dynamics and almost simple reproduction of generations were noted in Rivne, Transcarpathian and Volyn regions.
\end{abstract}

Key words: fertility, general fertility coefficient, total fertility rate, early birth, illegitimate births.

DOI: http://dx.doi.org/10.17721/2413-7154/2016.75.28-34

UDC: $911.3: 314.18(477)$

\section{СУСПІЛЬНО-ГЕОГРАФІЧНІ ДОСЛІДЖЕННЯ ПРОЦЕСІВ НАРОДЖУВАНОСТІ В УКРАЇНІ}

\author{
Ірина ГУДЗЕЛЯК \\ Львівський начіональний університет імені Івана Франка \\ ihudzelyak@gmail.com
}

\begin{abstract}
Анотація: В Україні протягом XX ст. народжуваність стабільно знижувалася, за винятком двох короткотривалих повоєнних періодів. 3 початку XXI ст. відбувається повільне зростання народжуваності після кризово низького рівня у 2001 р. Серед чинників, поряд з соціально-гендерними властивостями та специфічною демографічною структурою, найбільше впливає демографічна політика, тоді як рівень соціально-економічного розвитку справляє суперечливий і нетиповий вплив на рівень народжуваності. Стан репродуктивного здоров'я населення України незадовільний, це результат способу життя, вітальної поведінки, поширення абортів, особливо серед наймолодших вікових категорій. Загалом рівень абортів знижується, існують дуже суттєві просторові відмінності. Виявлено сучасні особливості вікової структури народжуваності, які важливі для оцінки стадії демографічного переходу та визначення нової моделі демографічної поведінки. Для Західного регіону характерна найнижча рання, за винятком Закарпатської області, і позашлюбна народжуваність. За показниками рівня, структури і тенденцій народжуваності проведено типологію регіонів України, виділено 10 груп, вказано головні просторові відмінності. Найбільш несприятливі тенденції народжуваності простежуються в Сумській, Чернігівській, Луганській, Донецькій, Харківській, Полтавській та Черкаській областях, позитивна динаміка та близьке до простого відтворення поколінь - у Рівненській, Закарпатській і Волинській областях.
\end{abstract}

Ключові слова: народжуваність, загальний коефіцієнт народжуваності, сумарний коефіцієнт народжуваності, рання народжуваність, позашлюбна народжуваність.

DOI: http://dx.doi.org/10.17721/2413-7154/2016.75.28-34

Удк: 911.3:314.18(477)

Актуальність теми. Народжуваність - иее один з елементів процесу відтворення населення, що формується під впливом дуже великої кількості соціально-економічних, політико-історичних, демографічних та психологічних факторів. У сукупності зі смертністю народжуваність зумовлює неперервність процесу відтворення поколінь. Суспільногеографічний аналіз процесів народжуваності в Україні включає детальне вивчення окремих

(C) I. Гудзеляк чинників, що впливають на народжуваність, а також ㄲi динаміку та структуру, територіальні відмінності, з'ясування особливостей цих процесів у порівнянні $з$ іншими країнами світу. Ці питання завжди є актуальними, адже величина i якість демографічного потенціалу й сьогодні залишаються вагомими передумовами розвитку окремих країн, тенденції народжуваності важливі 3 огляду на питання стратегічного планування та прогнозування майбутнього регіонального і державного розвитку. 
Аналіз останніх досліджень і публікацій. Питання, які стосуються аналізу динаміки i структури народжуваності в Україні, головними чином вивчаються економістами, зокрема вченими Інституту демографії та соціальних досліджень під керівництвом Е. М. Лібанової, яка $€$ автором багатьох наукових праць та головним редактором комплексних монографій з проблем демографічного розвитку, у тім числі й народжуваності. Окремі аспекти народжуваності представлені у працях таких вчених: Аксьонова С. Ю. (особливості народжуваності у жінок середнього віку); Герасименко Г. В. (оцінка впливу соціальних програм на динаміку народжуваності в Україні); Крімер Б. О. (демографічні результати запровадження допомоги при народженні дитини); КурилоI. О. (статистична оцінка пронаталістських заходів в Україні); Мельничук Д. П. (вплив сучасних тенденцій народжуваності в Україні на перспективи формування та майбутні характеристики людського капіталу); Пальян 3. О. (статистичний аналіз чинників та передумов народжуваності в Україні); Шевчук П. С. (структура народжуваності в Україні на початку XXI ст.). Суспільно-географічні праці, присвячені питанню народжуваності, стосуються переважно окремих регіонів (Джаман В. О., Нємець Л. М., Романів О. Я., Сегіда К. Ю., Яворська В. В.) і не охоплюють проблем загальнодержавного рівня.

Метою даного дослідження є визначення типів регіонів України за головними параметрами рівня, структури i динаміки народжуваності, а також чинників, що зумовлюють просторову диференціацію процесів народжуваності.

Виклад основного матеріалу. Природний рух населення, у тім числі народжуваність, залежить від багатьох чинників, які об'єднують у декілька груп: соціально-економічні, культурно-психологічні, демографічні. Їхній вплив на процеси народжуваності має свої особливості у різних типах суспільства і великою мірою залежить від інституційних основ у країнах.

Соціально-економічні чинники відіграють визначальну роль у відтворенні населення, адже впливають на рівень добробуту населення, розвиток охорони здоров'я, суспільні норми, освітній i культурний рівень населення, характер зайнятості та спосіб життя тощо. Із зростанням рівня заробітної плати, коефіцієнт народжуваності знижується. Областям України з середнім рівнем заробітної плати властиві значно вищі показники народжуваності, що пояснюється в першу чергу тим, що вплив рівня добробуту на показники народжуваності відбувається перш за все через культурний рівень населення. Адже із зростанням добробуту в людей розширюється коло інтересів (подорожі, туризм, спорт), зростають витрати на виховання дітей бо вимоги до якості дитячого населення також підвищуються. Окрім того, області України з високою зарплатою - це переважно високо урбанізовані регіони 3 новою моделлю репродуктивної поведінки.

Фактор зайнятості негативно впливає на зростання народжуваності, адже за умови високої зайнятості жінок знижується показник народжуваності [3]. Особливо низькою вона $є$ в Україні, де недостатньо розвинена соціальна інфраструктура з обслуговування потреб матерів 3 дітьми. Зниження зайнятості призводить до зниження доходів населення, тому народжуваність також буде зменшуватись. Однак, в Україні виявлено деякі специфічні риси - в період зростання безробіття у багатьох регіонах народжуваність навпаки підвищується, оскільки для багатьох сімей матеріальна допомога при народженні дитини розглядається як стабільне джерело грошових доходів. А період вимушеного безробіття жінки розглядають як вдалу можливість присвятити материнству.

Значний вплив на процеси народжуваності населення мають міграції. Еміграція зумовлена в основному високим рівнем безробіття, що у свою чергу суттєво впливає на стан демографічної ситуації певного регіону. За результатами досліджень у багатьох розвинених країнах саме безробіття, особливо молоді, безпосередньо визначає низьку народжуваність. В Україні також виявлено певні відхилення від європейських тенденцій: області $з$ найвищою народжуваністю - Рівненська, Закарпатська, Волинська та Житомирська характеризуються найвищим безробіттям. Це дає підстави говорити про те, що матеріальна допомога, яка виплачується державою при народженні дитини розглядається, i фактично $\epsilon$, єдиним джерелом існування багатьох сімей.

Міграція, зумовлена політичними чинниками, війнами, завжди у наслідку призводить до зниження народжуваності. Вплив цього чинника в Україні можна буде простежити лише тоді, коли буде змога отримати достовірну статистичну інформацію в регіонах, які охоплені конфліктом, а також простежити диференціальну народжуваність у районах масового вселення вимушених мігрантів.

Сучасний стан репродуктивного здоров'я населення України можна визначити як незадовільний. На нього впливають несприятливі соціальноекономічні, екологічні чинники, а також стани, зумовлені способом життя окремих соціальних груп, поширенням шкідливих звичок серед молоді, епідемій соціально небезпечних хворіб. Крім чинників, що зумовлюють погіршення здоров'я населення України в цілому, існує ряд факторів, пов'язаних безпосередньо з репродуктивною сферою, передусім - це поширення абортів. Рівень абортів в Україні за період незалежності істотно зменшився: 382,3 абортів на 1000 жінок репродуктивного віку у 1990 р. до 17,2 в 2014 р. Якщо у всьому світі співвідношення абортів до живонароджених становить 1:7, то в Україні число народжень почало переважати число абортів у 2001 р., проте співвідношення аборту до новонароджених становить 1:4,1 [4].

Регіональні відмінності у рівнях абортів суттєві: максимальний показник (Вінницька область - 15,95 на 1000 жінок фертильного віку) та мінімальний (Рівненська область - 5,72) відрізняються майже втричі [3]. Фахівці вказують на певну недо- 
реєстрацію здійснених абортів, передусім в Донецькій і Луганській областях, де ведуться воєнні діï. Позитивною ознакою останніх років $є$ помітне зменшення частоти абортів у дівчат-підлітків.

Узагальнено стан репродуктивного здоров'я населення відображає показник рівня безпліддя: за офіційною статистикою він $є$ невисоким 3,5-3,9 на 1000 осіб жіночого населення та 0,93 чоловічого. Водночас, за результатами соціологічних спостережень, рівень безпліддя в Україні становить 6,8\% від усіх сімей, або приблизно 1 млн подружніх пар [4].

Одним із найбільш вагомих чинників, які зумовили зростання народжуваності в Україні в останнє десятиліття, є проведення демографічної політики. Найбільш відчутне зростання сумарного показника народжуваності припало на період між запровадженням вагомої допомоги при народженні дитини у 2005 році та фінансово-економічною кризою 2008-2009 pp. У подальшому тенденція зростання сумарного показника народжуваності змінилась його стабілізацією на досягнутому рівні.

За період 2001-2013 р. найбільший приріст рівня народжуваності відбувся в Автономній Республіці Крим (переважно зросла народжуваність в ісламських сім'ях), Київській, Луганській, Донецькій областях, тобто у тих регіонах, де рівень народжуваності знижувався до критичних значень. Тоді як у західних областях темпи приросту рівня народжуваності виявилися найнижчими у країні. Можна припустити, що саме в Західному регіоні України починається перехід до європейської моделі демографічної поведінки, де матеріальні чинники втрачають своє значення, а на сході та півдні України фінансові заходи демографічної політики дали ліпший ефект.

Останне реформування фінансових заходів демографічної політики в Україні відбулося у березні 2014 р. 3 метою скорочення бюджетних витрат в умовах економічної кризи було встановлено фіксований розмір допомоги при народженні дитини - 41280 грн.

У кінці ХIX ст. Україна мала чи найвищий рівень народжуваності серед усіх європейських країн - 7,5 дітей у середньому на одну жінку репродуктивного віку, або 49\% (рис. 1). 3 кінця ХІХ ст. народжуваність почала різко знижуватися, особливо у роки першої світової війни. Пізніше - у 1930-их роках, коли колективізація цілком зруйнувала усталений уклад життя у сільській місцевості, відбувалися масові депортації, репресії та голодомор. Дуже коротке компенсаційне зростання народжуваності після другої світової війни швидко змінилося негативними тенденціями. У 1960 р. загальний коефіцієнт народжуваності знизився до 18,5\% і продовжував падіння до 10,8\%о у 2014 р. [1, 2, 3].

Найбільша кількість народжених була у 1983 р. - це діти повоєнного покоління, їхнє зростання це також результат посилення державної допомоги сім'ям з дітьми, яка була ухвалена союзним урядом у січні 1981 р. Загалом 31990 р. спостерігається плавне зменшення народжуваності як в міських поселеннях, так i в сільській місцевості, але швидші темпи зниження припадають саме на міське населення і скорочення становить 46\%, а в сільській місцевості 35\%. За період з 1990 по 2001 рр. чисельність новонароджених загалом в Україні скоротилася на 43\%, середньорічний темп зниження рівня народжуваності становив близько $4 \%$.

Історичний мінімум було зафіксовано 2001 р. всього 376,4 тис. дітей, або 7,7\%о (1,1 особа на одну жінку фертильного віку). Це найнижчий рівень народжуваності за усю історію демографічних спостережень. Після 2001 р. рівень народжуваності почав підніматися. У 2014 р. сумарний коефіцієнт народжуваності становив 1,498 осіб. Продовжує зберігатись тенденція перевищення сумарного рівня народжуваності в сільській місцевості $(1,827$ осіб) над міськими поселеннями (1,351 особи) країни.

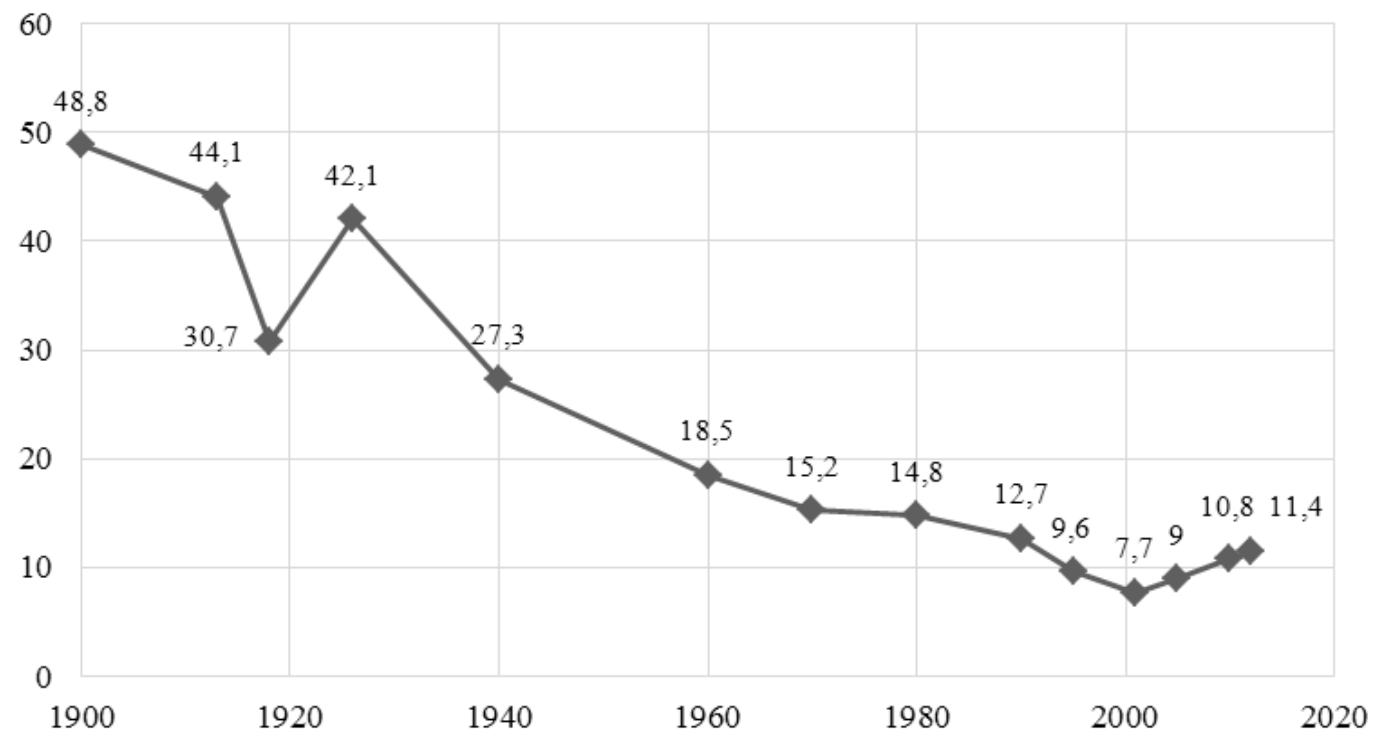

Рис. 1. Динаміка загального коефіцієнта народжуваності в Україні, \%о (побудовано за [2, 3]). 
Найвагомішими змінами народжуваності в Україні є: перехід до малодітності, відбувається трансформація вікової моделі народжуваності, тобто знижується рання народжуваність (це одна з головних ознак появи нової моделі народжуваності, подібної до європейської) і простежується «постарішання» материнства (зараз середній вік матері при народженні дитини становить 27,2 роки), відбуваються зміни у структурі народжуваності за черговістю народження, збільшується частка позашлюбних народжень [2]. Рівень позашлюбної народжуваності в Україні завжди був приблизно на середньоєвропейському рівні, а його динаміка синхронна $з$ європейськими тенденціями.

Регіони України помітно відрізняються за рівнем народжуваності. Найвищий коефіцієнт фертильності у 2014 р. був у Рівненській області [3]. Він відрізнявся від середньо українського рівня майже на $37 \%$, а від найнижчого в Україні значення у Сумській області-на $57 \%$. Серед регіонів з високим рівнем народжуваності - Волинська і Закарпатська області. Вище середнього рівня народжуваність у Чернівецькій, Львівській, Івано-Франківській, Одеській, Житомирській i Київській областях. Серед подільських областей найвища народжуваність у Вінницькій області. Північно-східні та південно-східні регіони, а також Черкаська область характеризуються найнижчою народжуваністю (рис. 2).

Спеціальний коефіцієнт народжуваності має певну специфіку у містах та сільській місцевості. Найнижчу народжуваність в міських поселеннях мають усі східні області, а також Черкаська, Тернопільська і Чернівецька, найвища - у Київській,
Волинській і Закарпатській областях. У сільській місцевості найнижча народжуваність спостерігається також у східних областях і Тернопільській області, а найвища - у Рівненській, де відбувається розширене відтворення. Волинська і Закарпатська області відзначаються простим відтворенням населення у сільській місцевості.

Рівень ранньої народжуваності становить 6\% від загальної кількості народжених [1]. Найнижчий рівень - у Львівській та Харківській областях. У міських поселеннях рівень ранньої народжуваності $4,2 \%$, у селах $-9,3 \%$. Найнижча рання народжуваність в Києві - 1,7\%, найвища - у Закарпатській області - 10,5\%. У сільській місцевості найнижча рання народжуваність у Львівській та Рівненській областях - відповідно 6,7\% та 6,9\%. Найбільша частка народжених матерями у віці до 20 років у сільській місцевості Кіровоградської (12,9\%) та Миколаївської $(12,5 \%)$ областей, дещо менша в Закарпатській, Херсонській, Вінницькій, Хмельницькій, Житомирській та Луганській областях (рис. 3).

За сумарним коефіцієнтом народжуваності проаналізовано темп зміни рівня народжуваності в Україні за період 1990-2014 рр. [3]. Найменше спад народжуваності фіксувався у таких областях: Київська $(96,7 \%)$, Одеська $(96 \%)$ та Рівненська $(95,7 \%)$. Що ж стосується найбільшого скорочення рівня народжуваності, то він був у Тернопільській (77,5\%), Черкаській (78\%), Івано-Франківській (78\%), Луганській $(78,4 \%)$, Сумській $(80 \%)$ та Херсонській (79,7\%) областях (рис. 4).

Для виявлення регіональних відмінностей процесу народжуваності в Україні застосовано

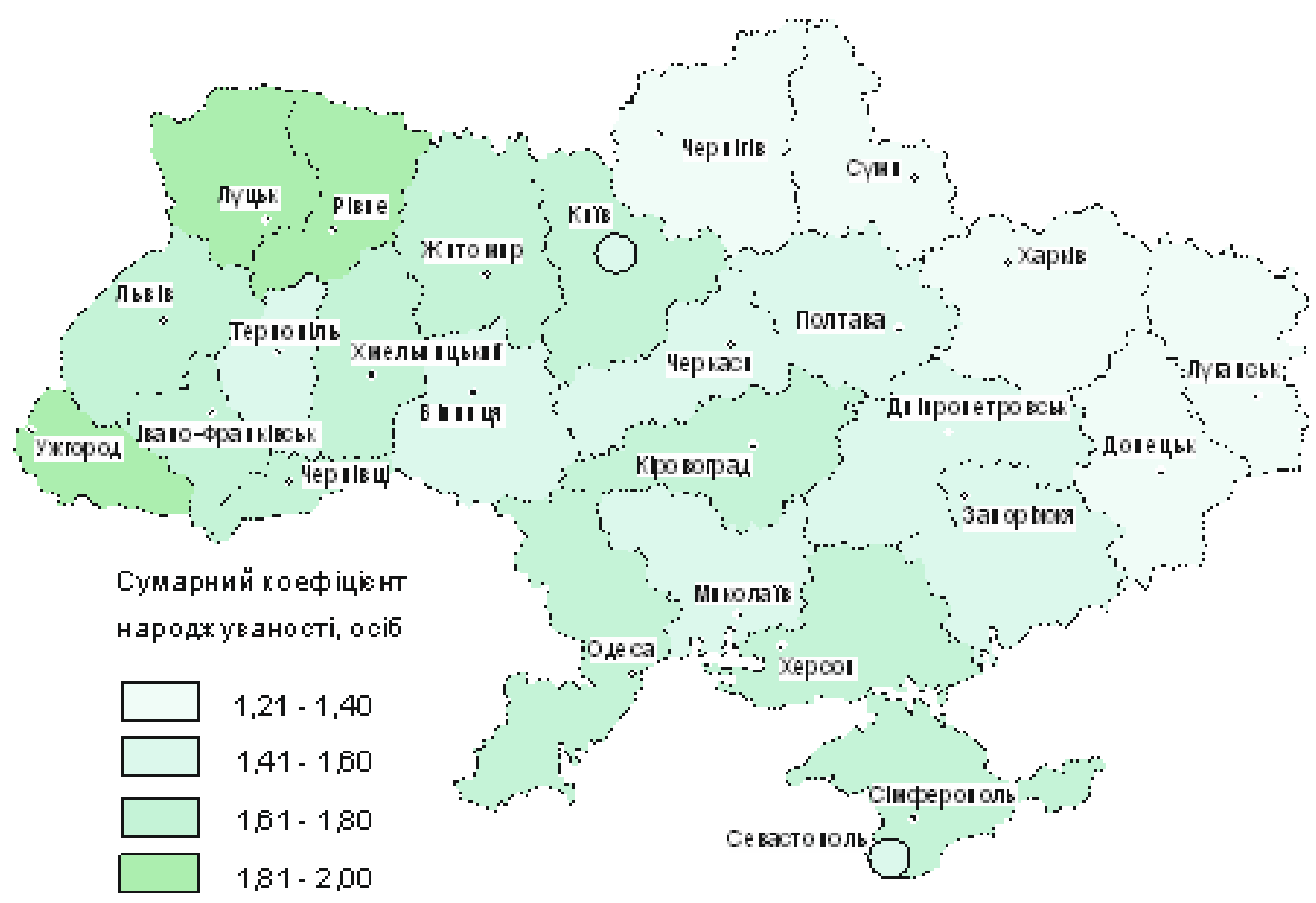

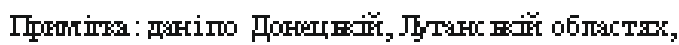
APK та M. Cе вастополь станом на 2013 p.

Рис. 2. Сумарний коефіцієнт народжуваності в Україні у 2014 р. (побудовано за [3]). 


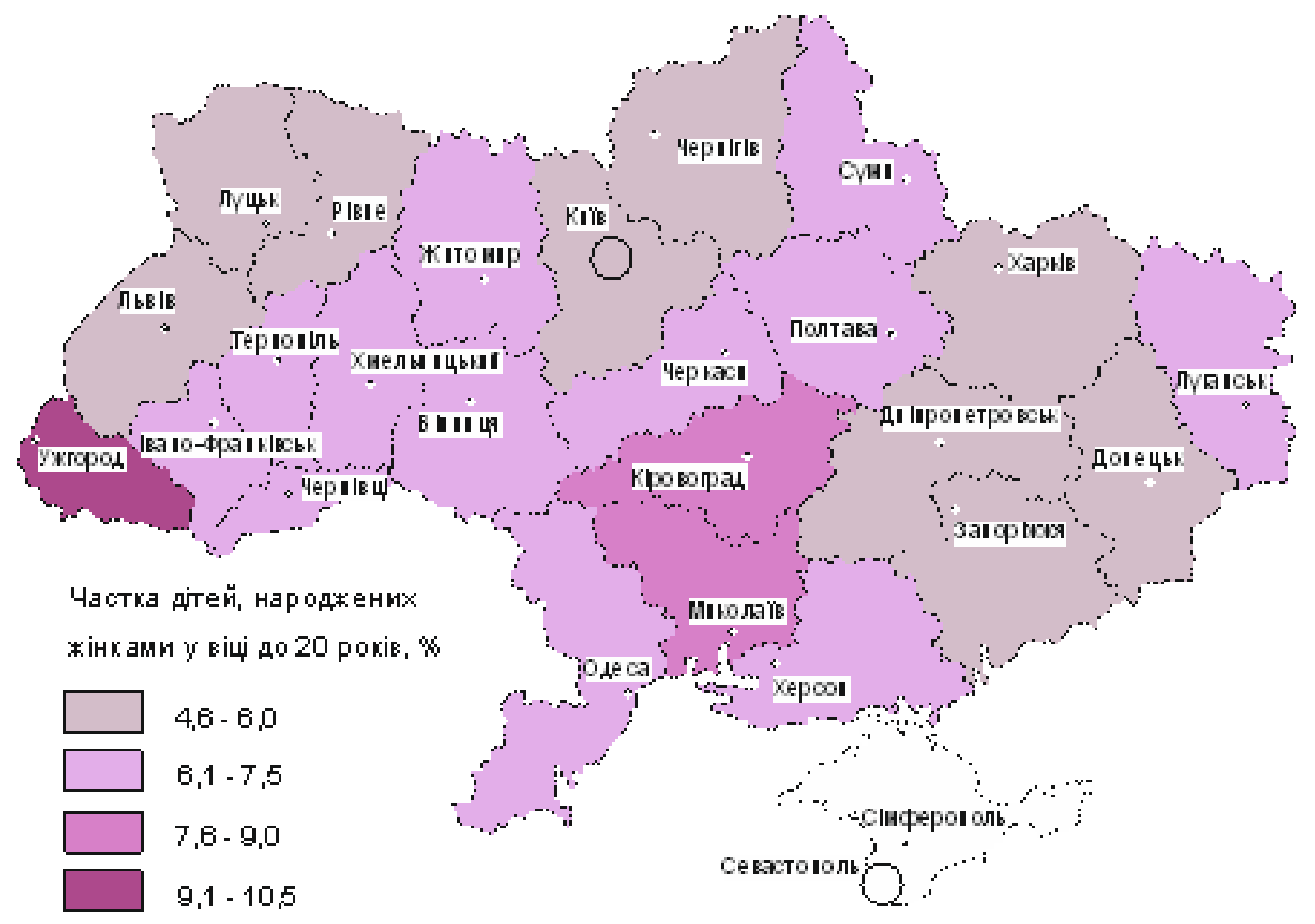

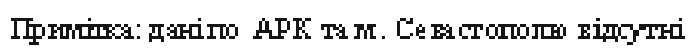

Рис. 3. Рівень ранньої народжуваності в Україні у 2014 р. (побудовано за [1]).

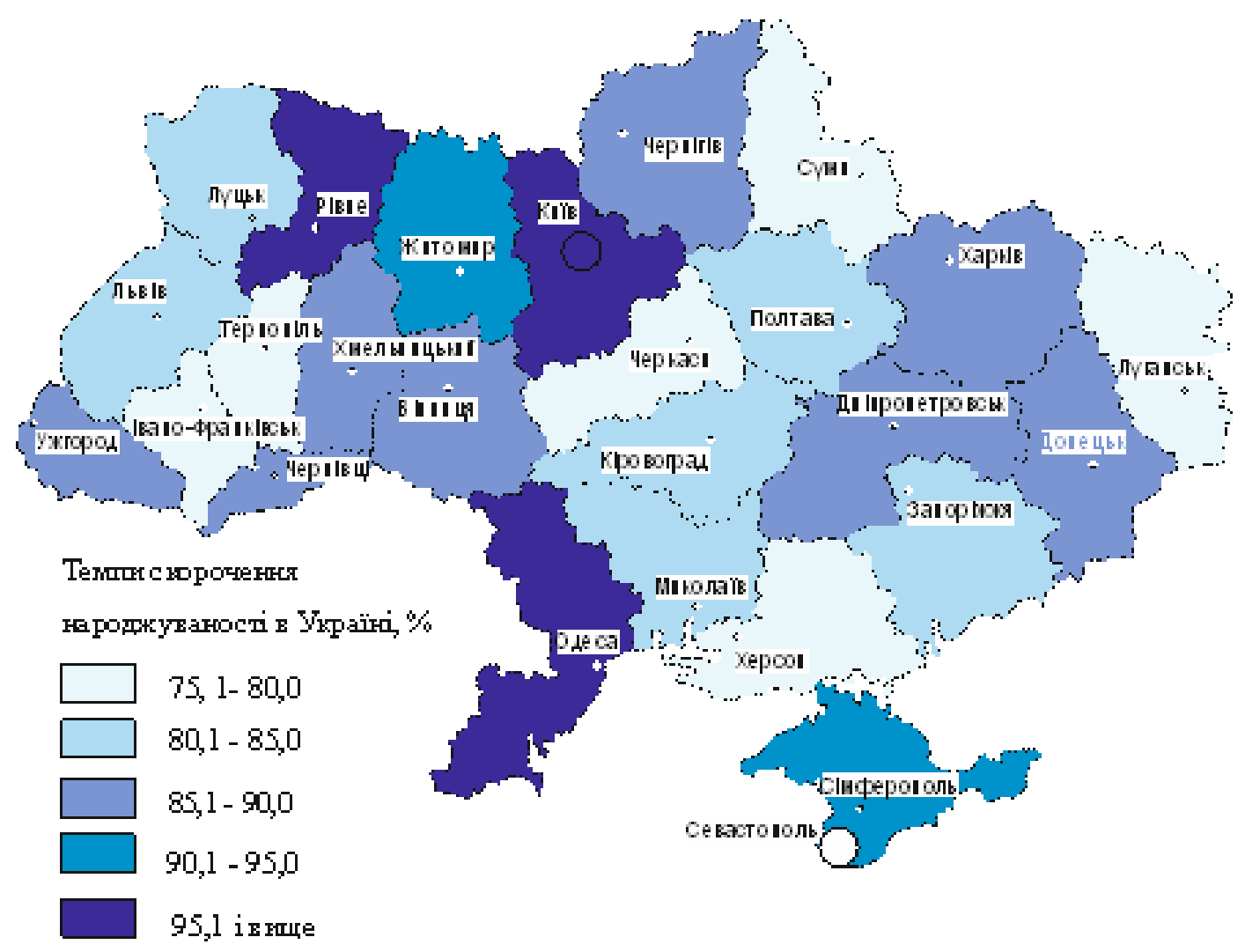

Рис. 4. Темпи зміни рівня народжуваності в Україні, 1990-2014рр. (побудовано за [3]). 
метод багатовимірного аналізу. На основі головних показників, що характеризують рівень, структуру i тенденції народжуваності у містах та сільській місцевості, виділено 10 груп областей $[1,3]$.

До першого таксону (рис. 5) належить Автономна Республіка Крим, для якої характерне несуттєве скорочення народжуваності за роки незалежності України, високий рівень народжуваності у сільській місцевості та достатньо сприятлива вікова структура народжуваності, висока позашлюбна народжуваність. Це такі риси, які властиві строкатому за типами демографічної поведінки населенню.

Друга група-Київська, Вінницька, Хмельницька і Кіровоградська області характеризуються середньо державними статистичними показниками рівня i структури народжуваності. Проте існують суттєві відмінності у показниках між міським i сільським населенням. Сільська місцевість (найбільше це виражено в Кіровоградській області) характеризується негативними тенденціями високої ранньої народжуваності та дуже високими показниками позашлюбної народжуваності.

До третього таксону увійшли переважно північно-східні та східні регіони - Чернігівська, Сумська, Полтавська, Харківська, Донецька, Луганська, а також Черкаська області. Це регіони 3 найнижчою народжуваністю.

Четвертий таксон об'єднує Дніпропетровську i Запорізьку області, де рівень народжуваності на середньо державному рівні, а рання і позашлюбна народжуваність, особливо у сільській місцевості вищі.
Окремим таксоном виступають Миколаївська та Херсонська області, в яких народжуваність вища від середньоукраїнського рівня, у тім числі висока рання і позашлюбна народжуваність у сільській місцевості.

Шостий таксон - Одеська і Житомирська області, які від попередньої групи відрізняються вищою народжуваністю, однак нижчою ранньою та позашлюбною народжуваністю. У сільській місцевості - народжуваність одна 3 найвищих в Україні, досягає рівня простого заміщення поколінь.

Рівненська та Волинська області належать до сьомого таксону. Вони характеризуються високою народжуваністю, розширеним відтворенням у сільській місцевості, низькою ранньою народжуваністю та найнижчою позашлюбною народжуваністю.

До восьмого таксону належать Івано-Франківська та Чернівецька області. Вони за рівнем і структурою народжуваності дуже подібні до наступної групи - Львівської та Тернопільської областей, проте відрізняються дещо вищою народжуваністю у сільській місцевості, у тім числі ранньою, а також дещо вищим рівнем позашлюбної народжуваності.

Дев'ятий таксон - Львівська і Тернопільська області. Львівська область - 3 високим рівнем урбанізації і найбільш наближеною до європейської моделлю репродуктивної поведінки: невисока народжуваність, найнижча в Україні рання народжуваність, у тім числі і в селах. Водночас, рівень позашлюбної народжуваності також найнижчий в Україні. Подібні тенденції властиві

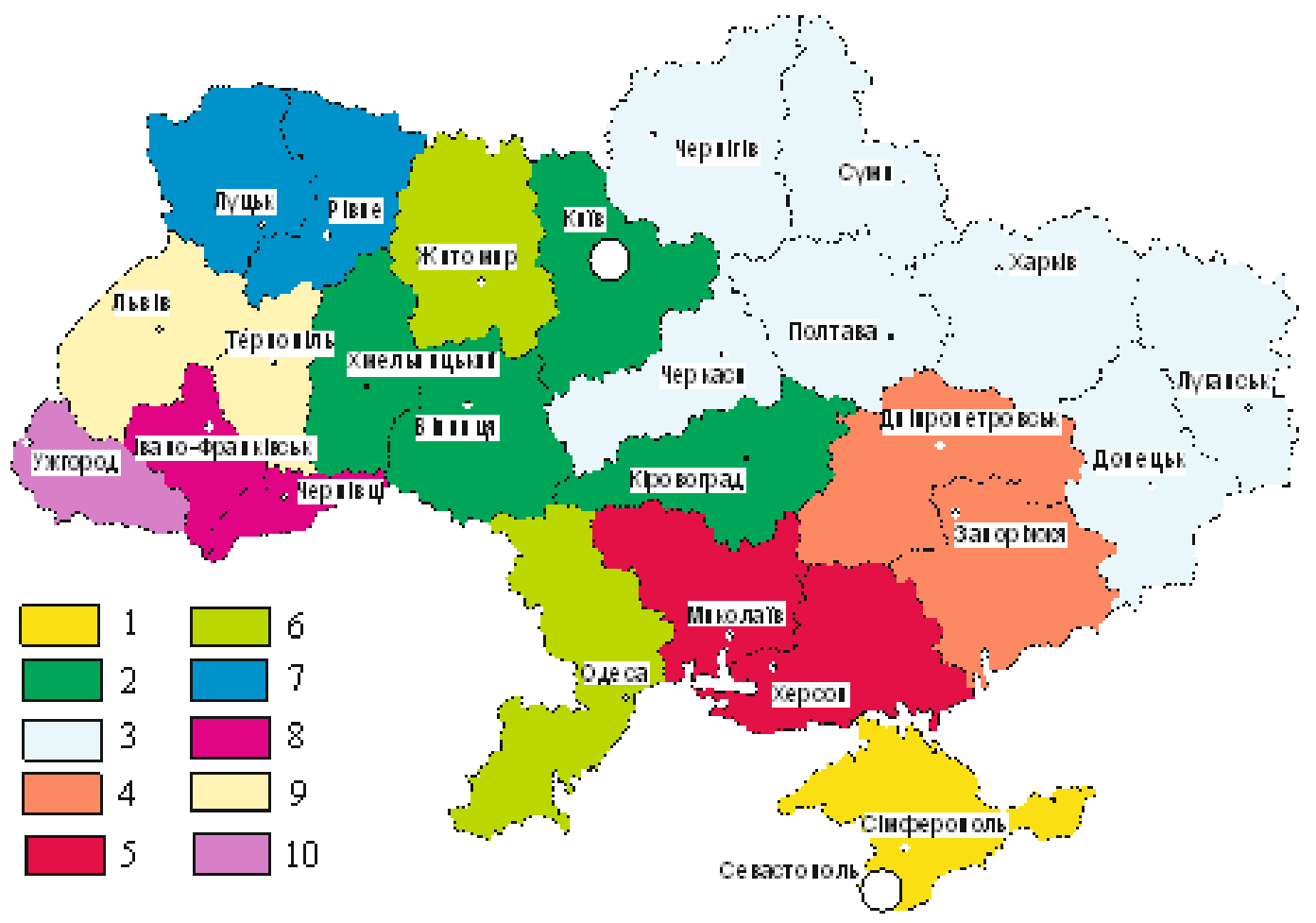

Рис. 5. Групування регіонів України за рівнем та структурою народжуваності, 2014 р. 
Тернопільській області, однак тут дещо вищий рівень ранньої народжуваності при дуже низькому загальному рівні народжуваності і в міських, і в сільських поселеннях, а також один 3 найнижчих рівнів позашлюбної народжуваності. За низьким рівнем народжуваності у сільській місцевості Тернопільська область порівнювана лише 3 Луганською та Чернігівською областями, де вікова структура населення суттєво деформована, а частка репродуктивних когорт надзвичайно низька.

Десятий таксон - це Закарпатська область, яка виділяється високим рівнем народжуваності і в міських, і в сільських поселеннях, високою ранньою народжуваністю (найвища в Україні), дуже низьким рівнем позашлюбної народжуваності.

Висновки. Найсприятливіша демографічна ситуація спостерігається на Закарпатті, Рівненській та Волинській областях. Характеризується додатним природним приростом, високим сумарним коефіцієнтом народжуваності. Найгіршу демографічну ситуацію було виявлено у Східному районі, у його областях найнижчі показники народжуваності.
Для підвищення рівня народжуваності в Україні слід проводити пронаталістську політику. Однак, як показують дослідження, модель репродуктивної поведінки змінилася. Повернутися до традицій середньодітної сім’ї надзвичайно складно. Тому напрями демографічної політики держави мають спрямовуватися передусім на підвищення рівня та поліпшення якості життя населення. Акценти варто робити не на кількісних, а на якісних параметрах демографічного відтворення. Їхнє вирішення передбачає розробку науково обгрунтованої комплексної програми подолання демографічної кризи, яка б охоплювала не тільки питання простого відтворення населення, але й його розвитку у широкому соціальному контексті.

Вагомим механізмом подолання демографічної кризи повинна стати нова міграційна політика, головною метою якої було б повернення з-за кордону українських мігрантів, кількість яких, за даними Міжнародної Організації Міграцій, становить приблизно 5,8 млн осіб.

\section{References:}

1. Naselennâ Ukraïni za 2014 rik. Demografičnij ŝoričnik. [Population of Ukraine in 2014. Demographic Yearbook]. Kyiv, 2015, 118 p. (In Ukrainian).

2. Naselennâ Ukraïni. Narodžuvanist'v Ukraïnì u kontekstì suspil'no-transformacìnih procesìv. [The population of Ukraine. The birth rate in Ukraine in the context of social transformation processes]. Kyiv, 2008,288 p. (In Ukrainian).

3. Official portal of the State Statistics Service of Ukraine. Access mode: http://ukrstat.gov.ua

4. Sorìčna dopovìd' pro stan zdorov'â naselennâ Ukraïni, sanìtarno-epìdemìologìcnu situaciû ta rezul'tati diâl'nostì sistemi ohoroni zdorov'â Ukraïni. 2014 rìk [Annual report on the state of health of Ukraine's population, sanitaryepidemiological situation and the results of the health system implementations in Ukraine. 2014]. Ed.: Kvìtašvìlì O. Kyiv, 2015, 460 p. (In Ukrainian). 